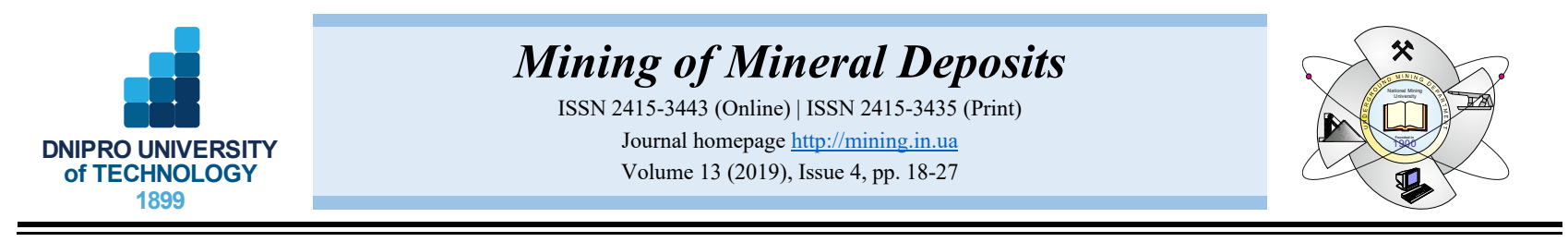

UDC 622.023 .23

https://doi.org/10.33271/mining13.04.018

\title{
NUMERICAL EXPERIMENTS CONCERNING LONG-TERM DEFORMATION OF ROCK SAMPLES
}

\author{
A. Olovyannyy ${ }^{1 *}$, V. Chantsev² \\ ${ }^{1}$ Saint-Petersburg Branch of the Federal State Budgetary Institution of Science of the Institute of Geoecology named after \\ E.M. Sergeev of the Russian Academy of Sciences, Saint-Petersburg, Russian Federation \\ ${ }^{2}$ Peter the Great Saint-Petersburg Polytechnic University, Saint-Petersburg, Russian Federation \\ *Corresponding author: e-mail agolov2009@hgepro.ru
}

\begin{abstract}
Purpose is to develop modeling methods of long-term rock sample deformation and failure under various loading conditions with the help of finite-element method of failure rock modeling (DESTROCK-FE).

Methods. DESTROCK-FE model describes rock as the non-linear viscoelastic-plastic breaking down medium. Creep strains are represented as viscoelastic ones, and viscoplastic strains are represented as the total of viscoelastic and failure strains. Destruction strains have been described by means of a model of the limited number of the oriented relaxation surfaces being calculated in accordance with shear and burst failure criteria. The calculations involved finite-element method for cylindrical samples. Numerical experiments have been carried out for following conditions: long-term creep under the permanent load; unloading strain after long-term creep strains; load relaxation in terms of the preset strain; and long-term strain in terms of gradual pressure increase. The research has involved rock-salt samples.

Findings. A model of rock as the non-linear viscoplastic failure medium has been added by a model of multidefective medium. It has been determined that general nature of rock creep curves under permanent load, unloading, and stress relaxations, obtained by means of calculations, correspond to the available scientific notations. The findings mean that the development of rock models should not involve successfully structural Maxwell element determining endless time-dependent strain growth. The strain velocity growth at the last stage of rock sample strain is stipulated by short-term and long-term accumulation of relaxations and failure.
\end{abstract}

Originality. It has been proved scientifically that viscous strains are described with the help of viscoelastic medium consisting of two Kelvin-Voigt elements as well as elements of short-term and long-term failure.

Practical implications. DESTROCK-FE modeling of one sample tested in terms of uniaxial compression has helped obtain parameters of elasticity, viscosity, and brittleness suitable for solving geomechanical and engineering problems in the context of mining.

Keywords: rocks, mathematical modeling, creep strains, stress relaxation, failure, finite-element method

\section{INTRODUCTION}

Rocks are viscous, i.e. they are deformed in time experiencing permanent load (i.e. creep strain) and lower stresses experiencing permanent strain (i.e. stress relaxation). Stress state varies within neighbouring rock mass during mining; in this context, strain process of the rocks, having viscous characteristics, takes much time. There are many models of viscous medium describing viscous effects with the help of analytical methods; however, we believe that the problem of rock mass modeling remains topical. The models, describing viscous strain down to failure, rely upon the experiments carried out during relatively short time periods. Generally, such models involve
Maxwell element or (if analytical dependences are meant) a positive degree time parameter determining possibility of endless strain growth (Zhao, Liu, \& Dong, 2011; Zhao, Chen, Zhao, Jie, \& Ning, 2012; Zou, Wang, \& Lai, 2013).

Abstract concepts, concerning long-term strain nature, in terms of the actual stresses resolve themselves into the following. When permanent stresses, being of less than long-terms strength, are acting, strain velocity decays and the strains are constrained (Fig. 1, curve 1). If the load excesses long-term strength, the strain experiences unlimited growth (Fig. 1, curves 2 and 3).

$A, B$, and $C$ periods are distinguished under long-term action of permanent load in the process of creep strain progress (Fig. 1, curve 2).

(C) 2019. A. Olovyannyy, V. Chantsev. Published by the Dnipro University of Technology on behalf of Mining of Mineral Deposits.

This is an Open Access article distributed under the terms of the Creative Commons Attribution License (http://creativecommons.org/licenses/by/4.0/),

which permits unrestricted reuse, distribution, and reproduction in any medium, provided the original work is properly cited. 


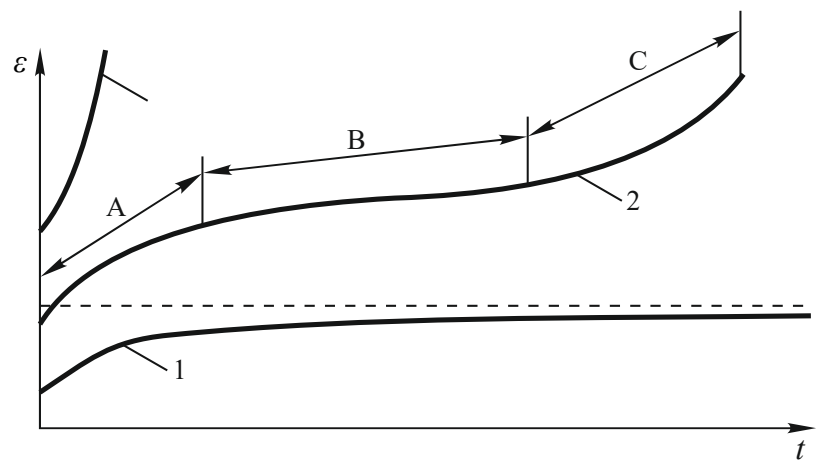

Figure 1. Graphs of time-dependent rock strain in terms of permanent load

$A$ - strain velocity loss (i.e. decaying or transitional creep);

$B-$ strain velocity is constant (i.e. stationary creep);

$C$-permanently accelerated velocity resulting in failure.

In the context of stresses, being close to failure ones, strain takes place with permanently increasing velocity (Fig. 1, curve 3). If unloading happens after sample is under strain during certain time period then recovery strains are observed. If initial loading is less than longterm strength (Fig. 2, curve 1) then immediate elastic strains $\varepsilon^{e}$ recover and complete recovery takes place with time. If the initial stresses excess long-term strength then elastic strains recover as well as certain part of viscous component of the strain (Fig. 2, curve 2). Resulting from viscous characteristics, relaxation effect begins to appear in rocks when decrease in the real loads is observed in terms of the recorded strains.

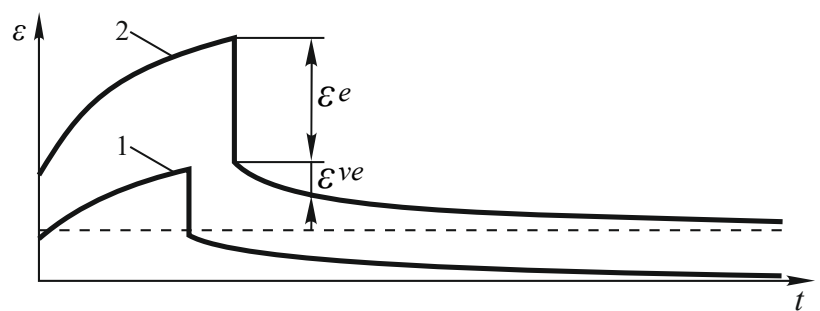

Figure 2. Graphs of time-dependent rock strain in terms of unloading

The paper considers viscous strain as viscoelastic one. Viscoplastic strain stage originates as the result of total viscoelastic strain as well as plastic strain and failure resulting in strain acceleration. Volume strains are determined by means of failure processes, and processes of plastic strain.

Using DESTROCK-FE model, (Olovyannyy \& Chantsev, 2018) paper lists the results of numerical experiments concerning rock-salt sample strain under the short-term laboratory tests. In this context, sample strain was modeled for following conditions: long-term creep in terms of permanent load; strain unloading after longterm creep strains; stress relaxation in terms of the preset strain; and long-term strain in terms of gradual pressure increase. The key feature of the DESTROCK-FE model is a procedure to calculate rock failure with the help of finite-element method.
The failure is calculated as the decreased shear adherence and tension strength in an element in terms of the limited lines (Olovyannyy, 2012). Nine lines are singled out in terms of axial symmetry (Fig. 3).

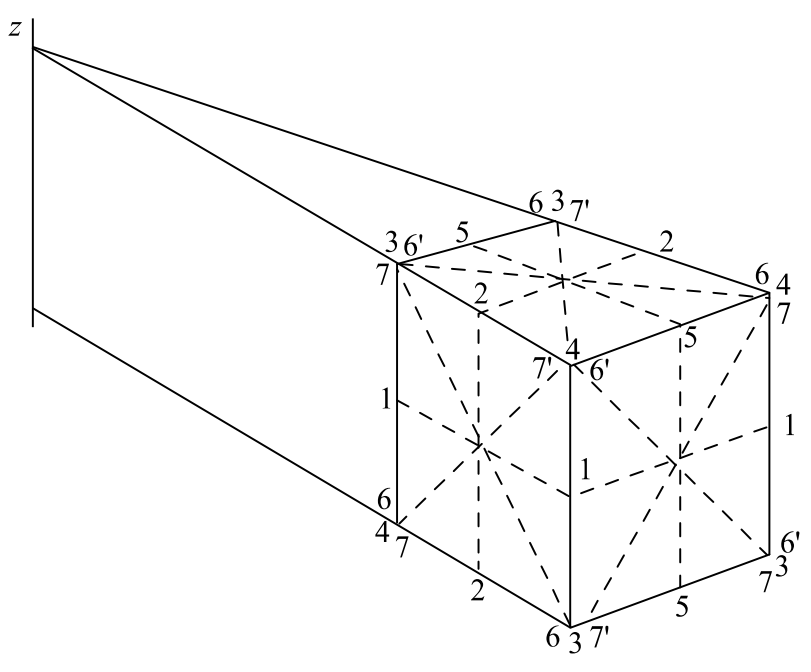

Figure 3. Scheme of the stipulated lines of possible relaxation developments in terms of axisymmetric strain

In the Figure 3, each of the systems (areas) is shown with the help of three or four equal numbers: 1-1-1, 2-2-2, $3-3-3-3,4-4-4,5-5-5,6-6-6-6,6^{\prime}-6^{\prime}-6^{\prime}, 7-7-7-7,7^{\prime}-7^{\prime}-7$.

\section{CREEP STRAIN IN TERMS OF DESTROCK-FE MODEL}

DESTROCK-FE model describe creep strain as the total of viscoelastic, plastic, and breaking strains. Viscoelastic strain is a recovering part of viscous strain. Structural rheological Kelvin-Voigt model visualized strain of viscoelastic material. Kelvin-Voigt element involves paralleled elastic component (1) and viscous component (2) (Fig. 4a).

(a)

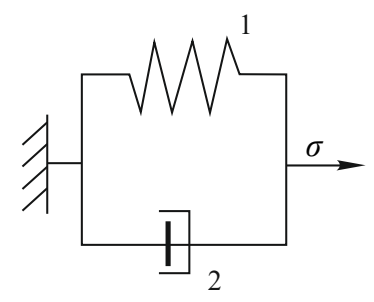

(b)

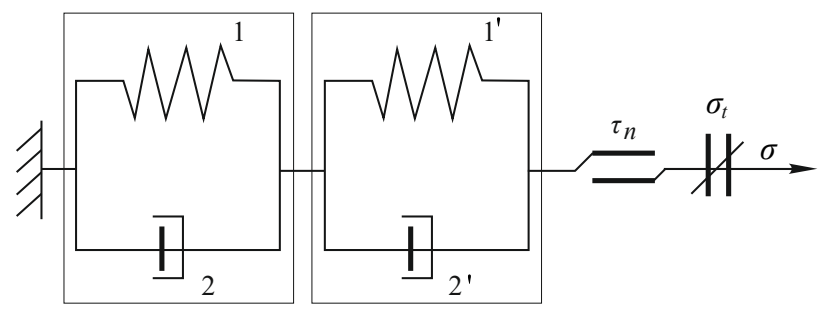

Figure 4. Structural rheological model of viscoelastic KelvinVoigt solid (a) and a model of viscoplastic failure solid with two Kelvin-Voigt components as well as failure components in terms of shear and failure (b) 
Elastic component is characterized by elasticity modulus $E_{1}$; viscous component is characterized by viscosity coefficient $\eta_{1}$. Strain $(\varepsilon)$-stress $(\sigma)$ ratio within the component is described by equation:

$$
\sigma=E_{1} \varepsilon+\eta_{1} \dot{\varepsilon}=E_{1}(\varepsilon+\theta \dot{\varepsilon}) \text {. }
$$

In terms of permanent load $\left(\sigma_{0}\right)$, Kelvin-Voigt solid experiences its strain tending over time to $\sigma_{0} / E_{1}$ value according to the law:

$\varepsilon=\frac{\sigma_{0}}{E_{1}}\left(1-\exp \left(-\frac{t}{\theta}\right)\right)$,

where:

$\theta$ - retardation period.

$\varepsilon_{\infty}^{v e}=\frac{\sigma_{0}}{E_{1}}$ value may be considered as equilibrium strain for the stress level.

It follows from (1) and (2) that the velocity of viscoelastic strain component can be determined by the current stresses as well as by the accumulated viscoelastic strains as:

$\dot{\varepsilon}=\theta^{-1}\left(\varepsilon_{\infty}^{v e}(\sigma)-\varepsilon^{v e}\right)$,

where:

$\varepsilon^{v e}$ - the accumulated viscoelastic strain;

$\varepsilon_{\infty}{ }^{v e}$ - equilibrium viscoelastic strain being tended to during long period of time in terms of the stress level.

Viscoelasticity equation, involving two degrees, is used to achieve better convergence of analytical and experimental graphs of strain dependence upon the time in terms of numerical calculations (Fig. 4b). In this case, velocity of viscous strain is:

$$
\frac{d \varepsilon^{v e}}{d t}=\theta_{1}^{-1}\left(\varepsilon_{\infty}^{(1)}(\sigma)-\varepsilon_{1}^{v e}\right)+\theta_{2}^{-1}\left(\varepsilon_{\infty}^{(2)}(\sigma)-\varepsilon_{2}^{v e}\right),
$$

where:

addends one and two describe $1^{\text {st }}$ (i.e. fast) and $2^{\text {nd }}$ (i.e. slow) degrees of viscoelastic strain $\left(\theta_{2}=k \theta_{1}\right)$.

In accordance with the specified scheme of structural state, while modeling, both fast creep and slow creep are considered independently. Paper (Zou, Wang, \& Lai, 2013) applies Burgers model to describe creep strain of clay. The model contains two Kelvin-Voigt elements, and Maxwell element. It is possible to mention a number of models by other authors containing Maxwell element, which describes endless strain growth. Basically, the proposed model does not contain series-connected Maxwell element. In terms of DESTROCK-FE model, possibility of strain acceleration results from accumulation of relaxations and failure. Complete model of viscous strains contains two viscoelastic Kelvin-Voigt elements, and two failure elements: $\tau_{n}$ in terms of shear, and $\sigma_{t}$ in terms of failure (Fig. 4b). The failure components determine instantaneous failure conditions as well as long-term accumulation of relaxations.

According to the isochronic strain graphs (Kartashov, Matveev, Mikheev, \& Fadeev, 1979; Glushko \& Vinogradov, 1982), if stresses are less than those of longterm strength, viscoelastic strains of many rocks are linear ones. Isochronic graphs of salt rock and oil shale (Fig. 5), mentioned in paper (Kartashov, Matveev, Mikheev, \& Fadeev, 1979), are linear within the certain load range. Argillite, aleurites, and sandstone sample tests (Glushko \& Vinogradov, 1982) means that if stress load of the samples is not more than $0.6 \sigma_{c}\left(\sigma_{c}\right.$ is compression strength) then stress-strain connection is almost linear for any time moment.

(a)

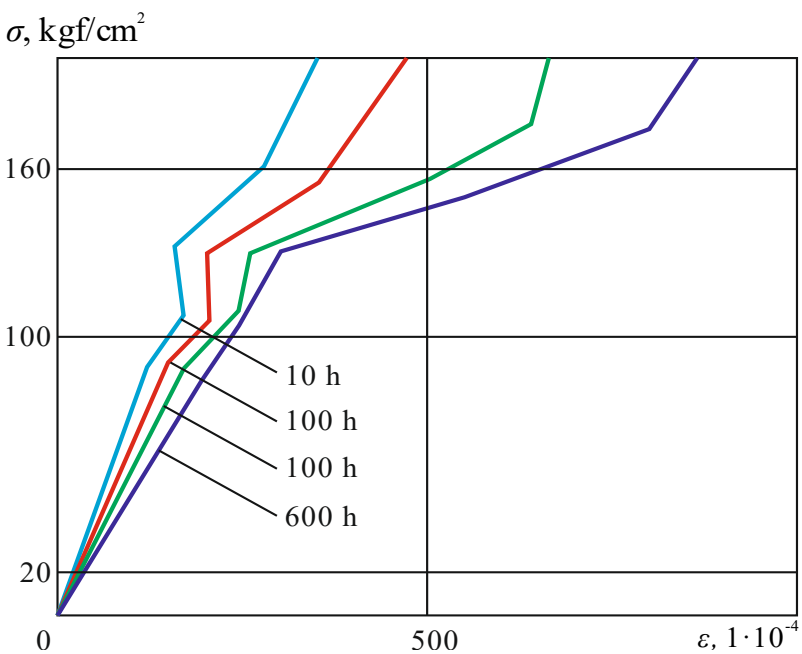

(b)

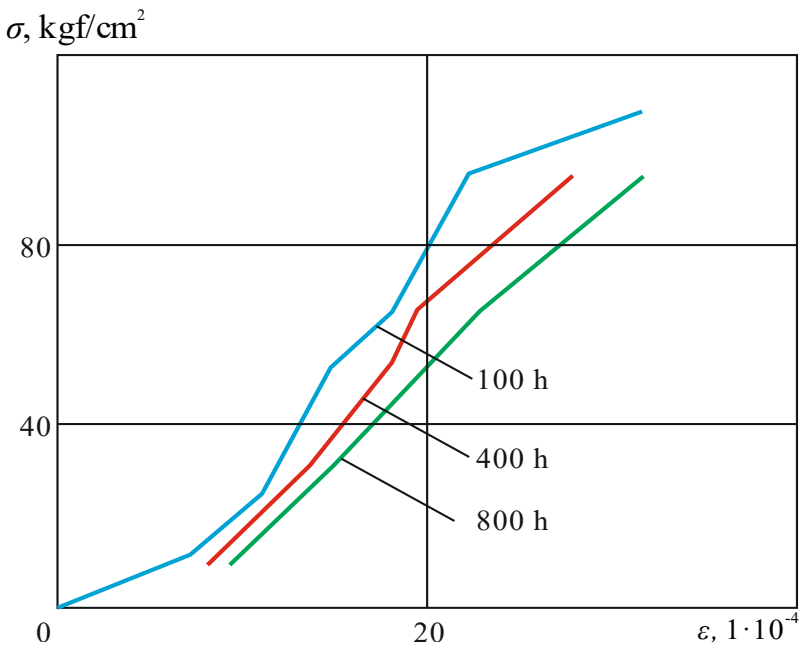

Figure 5. Isochronic graphs of salt rock strain (a) and oil shale strain (b) (Kartashov, Matveev, Mikheev, \& Fadeev, 1979)

Linear nature of the steady-state creep within a wide load range is supported by results of long-term tests of rock-salt samples (Zou, Wang, \& Lai, 2013) (Fig. 6).

In terms of load, when linearity is preserved, a value of the equilibrium viscoelastic strain for the stress state can be determined in shares of instantaneous elastic strain:

$\varepsilon_{\infty}^{v e}=K_{v e^{\varepsilon^{e}}}$.

Taking into consideration (4), the velocity of viscoelastic strain component is described using the expression:

$\dot{\varepsilon}=\theta_{1}^{-1}\left(K_{v e}^{(1)} \varepsilon^{e}-\varepsilon_{1}^{v e}\right)+\theta_{2}^{-1}\left(K_{v e}^{(2)} \varepsilon^{e}-\varepsilon_{2}^{v e}\right)$. 


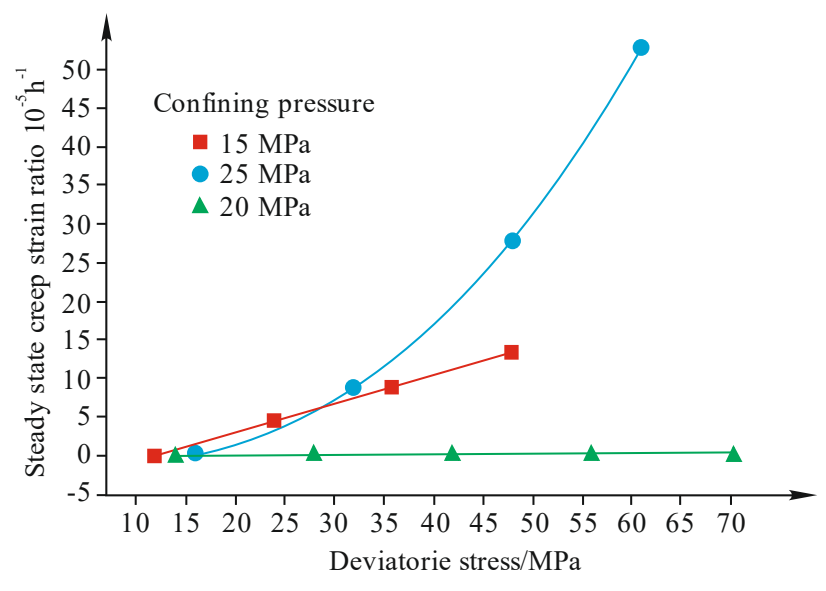

Figure 6. Relationship between the steady-state creep strain rate and the deviatoric stress (Zou, Wang, \& Lai, 2013)

In this context, $K_{v e}=K_{v e}^{(1)}+K_{v e}^{(2)}$. In terms of our calculations, $K_{v e}^{(1)}=K_{v e}^{(2)}=0.5 K_{v e}$ (Olovyannyi, 2016) papers consider $K_{v e}$ as an elastic viscosity coefficient (each rock has viscous characteristics. Over a long period of geological processes, viscoelastic strains achieve equilibrium values and effect formation of stress state within the rock masses. Together with Poisson's ratio, such characteristic of viscous properties as an elastic viscosity coefficient effects significantly stresses within the rock masses).

Characteristics of viscous strains may vary within defective medium and within solid material. In terms of the represented form (6), viscoelastic strains are not connected directly with disturbances. The connection exists indirectly through elastic strains, which shear decreases while breaking-down. The fact can be supported by creep graphs of the undisturbed rock-salt samples, and disturbed ones in terms of gradual loading mode (Il'inov, Kartashov, Karmanskiy, \& Kozlov, 2010). The research has shown that rock structure disturbance results in the decreased creep strains. In the context of strains, being similar as for strength, it depends upon the decrease in elastic strains acting within the disturbed rocks. In formulas for viscoelastic strain, i.e. (5) and (6), the fact is considered indirectly by each stage of the process.

Within the rock masses, rocks are almost everywhere under the conditions of confining pressure. To compare with shear strains, volume ones are minor. Equations (1) - (6) describe deformation strains.

It is reputed that in the majority of cases, viscous shear strains are either proportional to elastic ones or near them. It is important for further conclusions that viscous volume strains are minor, and thus may be ignored; i.e.:

$\varepsilon_{1}^{v e}+\varepsilon_{2}^{v e}+\varepsilon_{3}^{v e}=0$

where:

$\varepsilon_{1}{ }^{v e}, \varepsilon_{2}{ }^{v e}$ and $\varepsilon_{3}{ }^{v e}$ - the components of normal viscoelastic strains in terms of rectangular coordinate system.

If proportionality takes place then following ratios are reasonable for components of both viscous and elastic strains:

$$
\begin{aligned}
& \varepsilon_{1}^{v e}-\varepsilon_{2}^{v e}=k_{v e}\left(\varepsilon_{1}^{e}-\varepsilon_{2}^{e}\right) \\
& \varepsilon_{1}^{v e}-\varepsilon_{3}^{v e}=k_{v e}\left(\varepsilon_{1}^{e}-\varepsilon_{3}^{e}\right) ; \\
& \varepsilon_{1}^{v e}-\varepsilon_{1}^{v e}=k_{v e}\left(\varepsilon_{1}^{e}-\varepsilon_{1}^{e}\right),
\end{aligned}
$$

where:

$k_{v e}$ - the proportionality coefficient.

After summing upon left- and right-hand members of the inequalities, we obtain:

$$
3 \varepsilon_{1}^{v e}-\left(\varepsilon_{1}^{v e}+\varepsilon_{2}^{v e}+\frac{v e}{3}\right)=k_{v e}\left(2 \varepsilon_{1}^{v e}-\varepsilon_{2}^{v e}-\varepsilon_{3}^{v e}\right) \text {. }
$$

Using circular permutation of indices 1,2 , and 3 , we obtain two more similar expressions. Taking into consideration incompressibility condition (7), the equations help determine viscoelastic-elastic deformation ratio as follows:

$\varepsilon_{i}^{v e}=\frac{1}{2} k_{v e}\left(2 \varepsilon_{i}^{e}-\varepsilon_{j}^{e}-\varepsilon_{k}^{e}\right) ;$

$\gamma_{i j}^{v e}=k_{v e} \gamma_{i j}^{e}$,

where:

$\varepsilon_{i}^{e}, \varepsilon_{j}^{e}, \varepsilon_{k}^{e}, \gamma_{i j}{ }^{e}$ and $\varepsilon_{i}{ }^{v e}, \gamma_{i j}{ }^{v e}$ - the components of elastic strains and viscoelastic strains respectively; and $i, j$, and $k$ are numbers of axes of rectangular coordinate system $(1,2$, and 3 values are taken).

Numerical modeling calculates shear strain incremental in terms of three planes. Components of elastic deformations $\varepsilon_{i}^{e}, \gamma_{i j}{ }^{e}$, depending upon actual stresses, are calculated at each calculation interval within each element of the medium. Assuming that $k_{v e}=K_{v e}$, values of equilibrium viscoelastic deformations $\varepsilon_{\infty}{ }^{v e}, \gamma_{\infty}{ }^{v e}$ are calculated according to (10) formulas.

Taking into consideration (2), the increments of viscous deformations during time interval $\Delta t$ are calculated on formulas:

$$
\begin{aligned}
& \Delta \varepsilon_{i}^{v e}=\left(\frac{1}{3} K_{v e}\left(2 \varepsilon_{i}^{e}-\varepsilon_{j}^{e}-\varepsilon_{k}^{e}\right)-\varepsilon_{i}^{v e}\right) \times \\
& \times\left(1-\exp \left(-\frac{\Delta t}{\theta}\right)\right) \\
& \Delta \gamma_{i j}^{v e}=\left(K_{v e} \gamma_{i j}^{e}-\gamma_{i j}^{v e}\right) \cdot\left(1-\exp \left(-\frac{\Delta t}{\theta}\right)\right) .
\end{aligned}
$$

Deformation increments on formulas (11) are calculated independently for degree one and degree two.

\section{VISCOPLASTIC AND MICRO- DEFECT STRAINS, AND FAILURE}

The problem of creep description within the accelerated strain area (i.e. viscoplasticity) is solved by means of viscous, plastic, and failure deformation adding. Scheme of structural rheological model (Fig. 3b), involving both viscous and breaking components, provides general idea of strain laws. The modified Mohr-Coulomb criterion is applied to determine possibility of failure over the surfaces (Olovyannyy, 2018), taking into consideration Barton's concept of shear strain limitation 
during rock disintegration (Barton, 1976; Barton, 2013; Shen, Shi, \& Barton, 2018). The criterion formulates fracture conditions within the areas of shear and separation in the following way:

$$
\begin{aligned}
& \left|\tau_{n}\right|=C \omega_{n}+\sigma_{n} \tan \left[\varphi\left(1-\xi_{2}\left(1-\omega_{n}\right)\right)\right], \\
& \sigma_{n}>0 ; S<\xi_{1} E ; \\
& \left|\tau_{n}\right|=C \omega_{n}+\sigma_{n}\left(\frac{S}{\xi_{1} E}\right)^{a} \tan \left[\varphi\left(1-\xi_{2}\left(1-\omega_{n}\right)\right)\right], \\
& \sigma_{n}>0 ; S<\xi_{1} E ; \\
& \sigma_{n}=\omega_{n} \sigma_{t},
\end{aligned}
$$

where:

$S=\sigma_{1}+\sigma_{2}+\sigma_{3}-$ the total of basic stresses;

$E$ - elasticity modulus;

$\sigma_{t}-$ tension strength;

$C$-adhesion;

$\varphi$ - internal friction angle;

$\omega_{n}-$ strength loss parameter (i.e. continuity);

$\xi_{1}$ and $\xi_{2}$-the constants being determined during modeling laboratory experiments with samples;

$a$ - parameter identifying nature of the fracture criterion.

The first two equalities in criterion (12) represent failure conditions over sites in terms of share; the latter one - strength condition in terms of tension. The failure condition in terms of share (12) if $a=0$ is MohrCoulomb failure criterion (M-C) added by a possibility to change friction angle depending upon loosening degree over shear area. If $a=1$, then the condition is non-linear criterion with the limited increase in breaking shear stresses in accordance with Barton; if $0<a<1$, then we have non-linear criterion with the unlimited increase in breaking shear stresses; and if $a>1$, then non-linear criterion with the limited increase and further decrease in the breaking shear stresses in terms of confining pressure increment is meant.

The parameter, identifying failure possibility within the area, i.e. load degree, is calculated taking into account (12) and using the formulas:

$$
\begin{aligned}
& C=\frac{\left|\tau_{n}\right|}{\left\{C \omega_{n}+\sigma_{n} \tan \left[\varphi\left(1-\xi_{2}\left(1-\omega_{n}\right)\right)\right]\right\}}, \\
& \sigma_{n}>0 ; S<\xi_{1} E ; \\
& C=\frac{\left|\tau_{n}\right|}{\left\{C \omega_{n}+\sigma_{n}\left(\frac{S}{\xi_{1} E}\right)^{a} \tan \left[\varphi\left(1-\xi_{2}\left(1-\omega_{n}\right)\right)\right]\right\}}, \\
& \sigma_{n}>0 ; S>\xi_{1} E ; \\
& C=\frac{\sigma_{n}}{\omega_{n} \sigma_{t}}, \sigma_{n}<0 .
\end{aligned}
$$

If the load degree exceeds relative long-term strength, i.e. $C>C_{\mathrm{l}}$, then processes of plastic strain and failure are in progress. Certain part of the material strength is lost as the result of plastic strain, shear, or failure. Strength increment is calculated depending upon increments of breaking or failure strains:
$\Delta \omega=-M \gamma\left|\Delta \gamma_{n}^{d}\right|+M_{n} \Delta \varepsilon_{n}$,

where:

$\Delta \gamma_{n}{ }^{d}$ - increment of plastic shear strains and breaking ones;

$\Delta \varepsilon_{n}$ - increment of breaking tension strain;

$M_{\gamma}$ and $M_{n}$ - the local decrease moduli during shear and tension respectively.

Both shear and breaking strains are followed by the increase in volume resulting from normal line tension strains towards failure surface:

$\Delta \varepsilon_{n}=-K_{v} F_{v}\left(\tau_{n}, \sigma_{n}\right)\left|\Delta \gamma_{n}^{d}\right|$,

where:

$F_{v}\left(\tau_{n}, \sigma_{n}-\right.$ a dilatancy function:

$F_{v}\left(\tau_{n}, \sigma_{n}\right)=\frac{\left|\tau_{n}\right|}{\left|\tau_{n}\right|+\left(1.6-K_{v}\right) \sigma_{n}}$,

where:

$\tau_{n}$ and $\sigma_{n}-$ shear strains and normal strains;

$K_{v}$ - a volume dilatation parameter.

Processes of long-term failure (i.e. strength loss) are considered with the help of long-term strength function:

$\theta=A[\exp (1-C)-1]$,

where:

$A$ - a constant value being determined using a condition of the specified duration before fracture (i.e. $\theta=T$ years if $C=C_{1}$ ); calculations assume that $T=100$ years.

If time increment is not equal to zero at the calculation stage $(\Delta t>0)$ then strength loss takes place within the element area being analyzed (i.e. adhesion value is down):

$\Delta C=-\frac{C+\sigma_{n} \tan \varphi}{a c(\theta+1)} \Delta t$.

Tension results in the decreased tensile strength in accordance with the decreasing continuity:

$\Delta \omega=-\frac{\omega}{[\alpha c(\theta+1)]}$.

Failure in a shear mode factors into the increased breaking shear strains over corresponding area as well as dislodging strains connected with it:

$\Delta \gamma_{n}^{d}=\frac{\Delta \omega}{M_{c}} \operatorname{sign}\left(\tau_{n}\right)$

$\Delta \varepsilon_{n}^{d}=-\left|\Delta \gamma_{n}^{d}\right| F_{v}(\sigma, \tau)$.

In the context of a failure in a tensile mode, viscoelastic failure strains grow towards normal line to a corresponding area:

$\Delta \varepsilon_{n}^{d}=-\frac{\Delta \omega}{M_{n}}$. 
Increments of plastic, viscoplastic, brittle (i.e. those braking during bursting), viscoelastic, and microdefect strains are calculated at each calculation stage for each component as well as strength increments for each of the separated lines. At the following stage, calculation is performed taking into consideration increments of secondary forces within the nodes of network of elements determined relying upon nonelastic strain increments.

When samples are tested under the conditions of uniaxial compression, nonlinear section of strain graphs is observed at the initial loading stage. The section reflects microdefect effect, i.e. microfissures, pores, and microinclusions (Fig. 7). Additions have been introduced to consider effect of the microfissures and pores for such a medium strain description (Olovyannyy, 2018). Microdefect medium (i.e. microinclusions) is a certain part of defective material, which strain rules differ from the basic material strain rules. Characteristics of the microdefect medium are as follows: the medium is viscous and its manifestations depend heavily upon loading velocity; and the strains are reversible and compressive strains are limited. At a phenomenological level, behaviour of such a medium is described with the help of viscoelastic medium strain equations.

Increments of viscous strains of microdefect medium in terms of $i^{\text {th }}$ line of the key stresses over time period $\Delta t$ are calculated on formula:

$\Delta \varepsilon_{m d}^{i}=\left(\epsilon_{i}-\varepsilon_{m d}^{i}\right)\left(1-\exp \left(-\eta_{m d} \Delta t\right)\right)$,

where:

$\epsilon_{i}-$ ultimate strain of the microdefects in the context of the strain level;

$\varepsilon_{m d}^{i}$ - achieved strain level;

$\eta_{m d}-$ coefficient of the microdefect viscosity.

The value of ultimate strain of microdefects in $i^{\text {th }}$ line of the key stresses is calculated like for the nonlinear elastic medium:

$$
\epsilon_{i}=\left\{\begin{array}{l}
\frac{\left[\sigma_{i}-0.5 K_{v}\left(S-\sigma_{i}\right)\right]\left[1-\left(1-\frac{E_{m d}}{E}\right) \frac{\varepsilon_{m d}^{i}}{e_{m d}}\right]}{E_{m d}}, \\
\frac{\varepsilon_{m d}^{i}>0 ;}{\left[\sigma_{i}-0.5 K_{v}\left(S-\sigma_{i}\right)\right]} E_{m d}, \varepsilon_{m d}^{i}<0 .
\end{array}\right.
$$

where:

$\varepsilon_{m d}-$ maximum possible compression strain (i.e. efficient mechanical openness);

$E$ - elasticity modulus;

$E_{m d}$-elasticity modulus of microdefect medium during tension.

(22) and (23) formulas describe microdefect medium as nonlinear-elastic one. Elasticity modulus is minimal within the tension branch. Within a compression strain branch, elasticity modulus varies from modulus during tension to elasticity modulus of material when ultimate compression strain is achieved.

\section{NUMERICAL EXPERIMENTS OF LONG-TERM SAMPLE DEFORMATION}

The research has been carried out with the use of model parameters obtained as a result of rock-salt sample tests in terms of axial compression of cylindrical sample with $100 \mathrm{~mm}$ height, $50 \mathrm{~mm}$ diameter, and constant $0.5 \mathrm{~mm} / \mathrm{min}$ velocity. Parameters of the model have been selected in the process of the sample deforming simulation. The modified Mohr-Coulomb criterion with $a=0$ parameter has been applied as a failure criterion (12). Figure 7 represents graphs of stress-strain analytical dependences and experimental dependences.

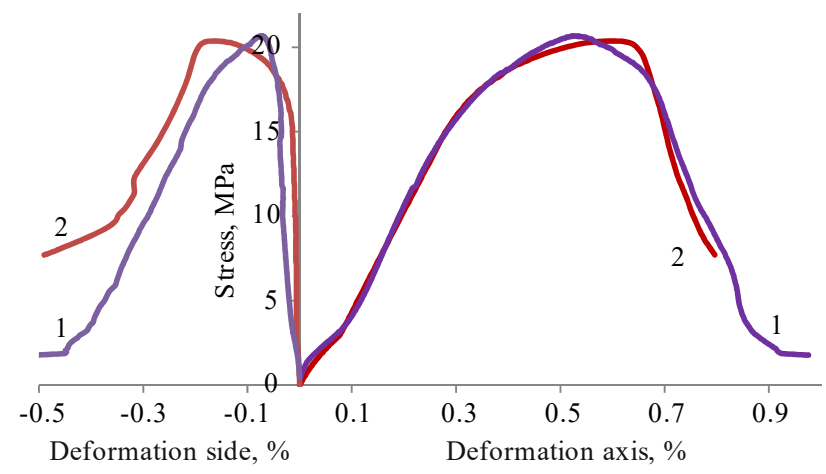

Figure 7. Graphs of deformation of cylindrical rock-salt sample resulting from experiments (1) and modeling (2)

DESTROCK-FE method has been used during numerical experiments of long-term deformation in the context of various conditions of rock sample loading.

\subsection{Creep deformations}

Figure 8 demonstrates graphs obtained as the result of simple deformation modeling in terms of constant axial loads.

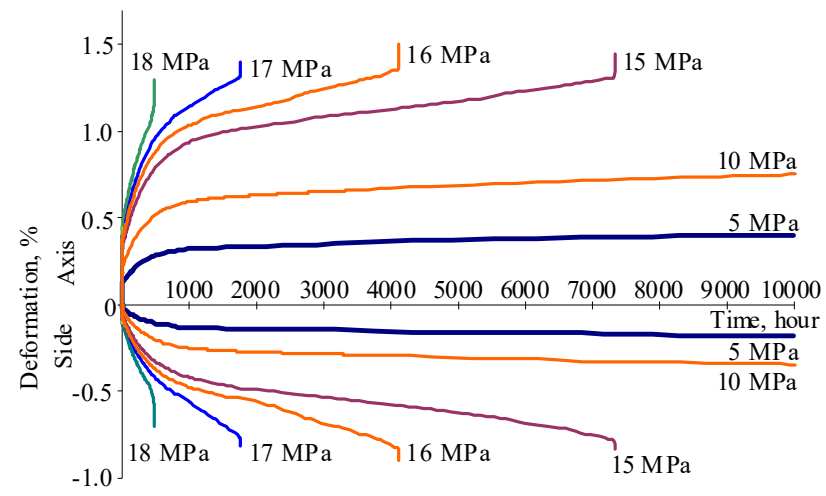

Figure 8. Analytical graphs of the sample creep in terms of constant pressure

The obtained time-dependent deformation curves in terms of constant loads involve areas deceleration, steady-state creep, and deformation acceleration corresponding to scientific notations (Fig. 1).

\subsection{Recovery during unloading}

The graphs, represented in Figure 9, demonstrate regularities of sample deformation during unloading. Recovery of elastic deformations during unloading is observed as well as recovery of viscous deformations. 
(a)

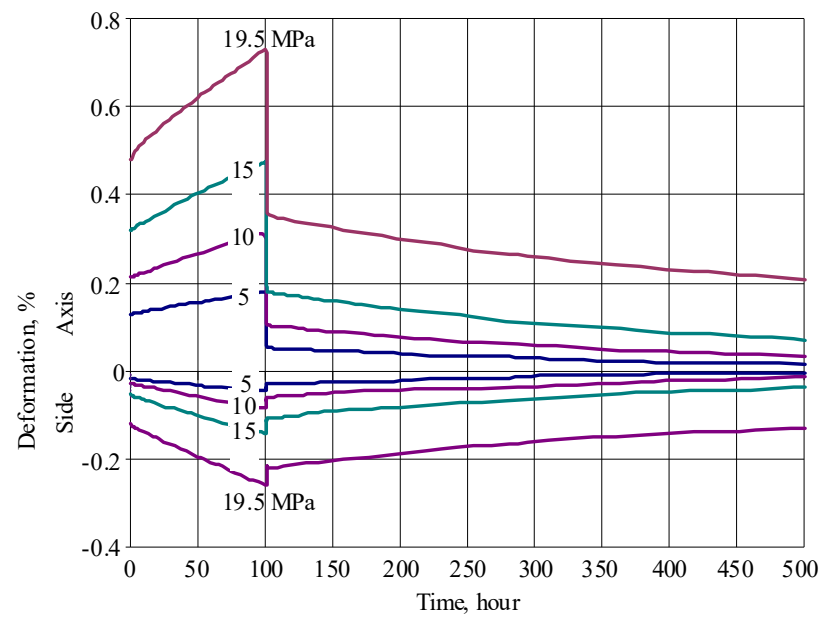

(b)

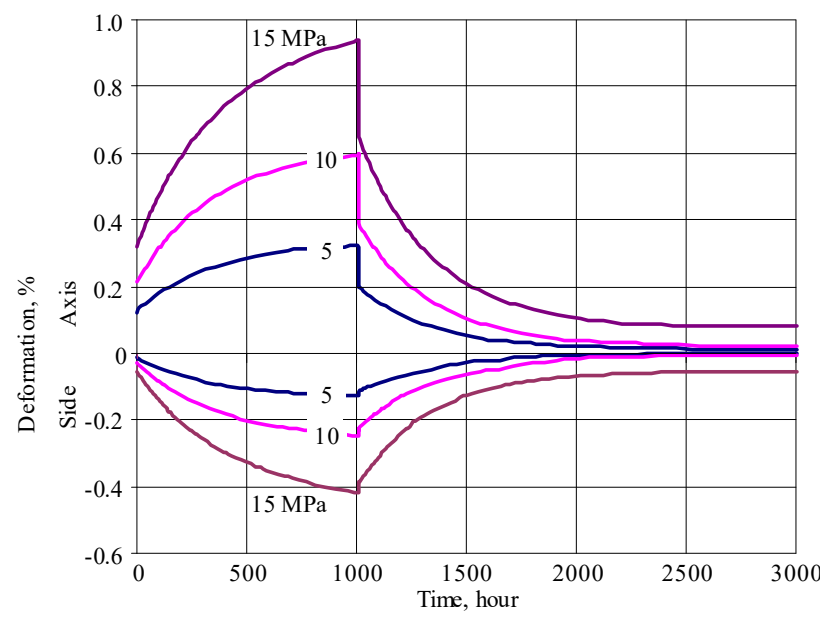

Figure 9. Analytical graphs of the sample creep in terms of constant pressure up to 100 hours (a) and up to 1000 hours (b) with its following unloading

And conservation of the accumulated irreversible deformations during a long period. The curves, resulting from the modeling, correspond to theoretical models (Fig.2).

\subsection{Stress relaxation}

Situation of a sample state is modeled with constant axial deformation conservation of the pre-loaded sample. The three alternatives have been considered: cylindrical sample is loaded with constant deformation velocity up to the specified deformation levels being $0.2,0.3$ and $0.4 \%$ remaining under the specified state during a long-term period. Figure 10 shows analytical graphs of changes in the pressure exerting on the load during the extended period.

\subsection{Gradual loading}

Figure 11 demonstrates results of the numerical experiment aimed at gradual sample loading. The sample deformation has been modeled with such different side loads as $0,5,10,15 \mathrm{MPa}$. Axial $5 \mathrm{MPa}$ load was specified at stage one. Then, after each 50 hours, the load was increased by $5 \mathrm{MPa}$. Load at stage one and following stages was increased with $100 \mathrm{MPa} / \mathrm{h}$ velocity. The cycling loading lasted up to the sample failure.

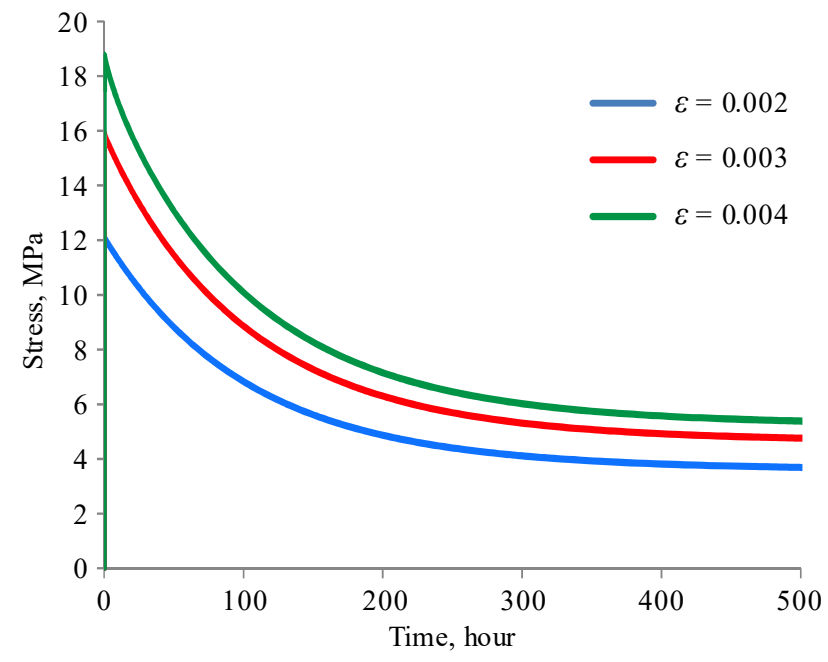

Figure 10. Analytical graphs of stress relaxation in terms of constant sample deformation conservation

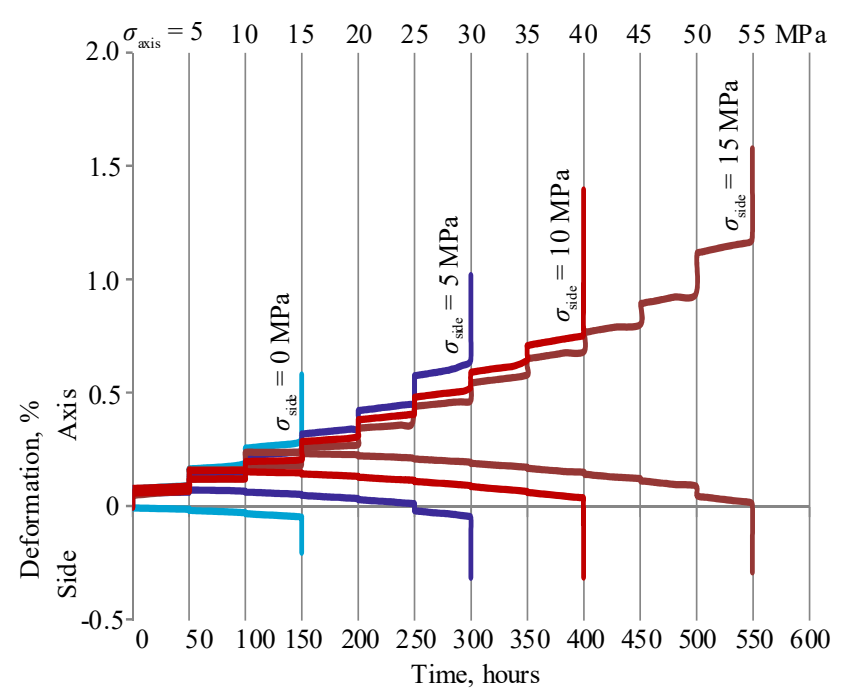

Figure 11. Deformation graphs in the context of gradual axial and triaxial sample loading in terms of $5 \mathrm{MPa}$ axial pressure increase and 50 hour phase period

The results of laboratory experiments in terms of cyclical sample loading in combination with numberical modeling are used to obtain deformational and strength parameters of rocks (Zou, Wang, \& Lai, 2013). Paper lists patterns of strength weakening in rock-salt sample sections during long-term loading at a failure moment (Fig. 12). Disturbances were only observed within a midsection of the sample (the mentioned does not specify conditions under which the result was obtained).
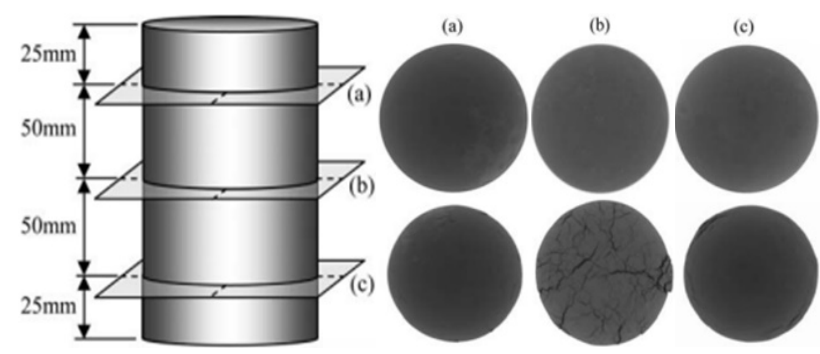

Figure 13. The sample patterns before creep test and after it: (a) top of the sample; (b) central part of the sample; (c) bottom of the sample (Zou, Wang, \& Lai, 2013) 
In the context of numerical modeling, the weakening in longitudinal sections, shown in Figure 13, differs depending upon the loading conditions. (a)

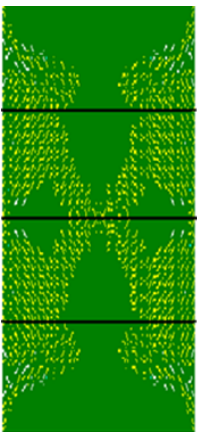

(b)

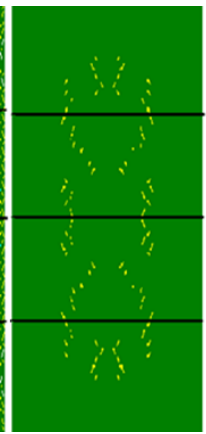

(c)

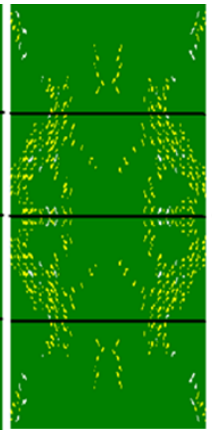

(d)

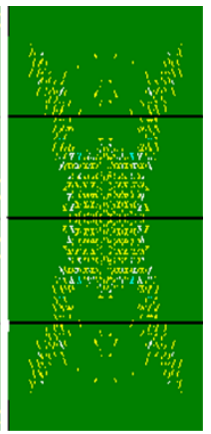

Figure 14. Analytical weakening patterns in the sample sections in terms of axial pressure: (a) when fast loading takes place as well as total loss of carrying ability; (b) when constant $18 \mathrm{MPa}$ pressure takes place at an intermediate stage; (c) when constant $18 \mathrm{MPa}$ pressure takes place at a moment forgoing total loss of carrying ability; (d) in the context of a numerical experiment when microdefect deformations are not available as a moment forgoing total loss of carrying ability

\section{CONCLUSIONS}

Numerical experiments of long-term modeling of rock samples have been carried out with the use of DESTROCK-FE method. The model parameters were determined relying upon optimum coincidence of experimental and analytical graphs of the sample deformation in the context of parameter selection. Since DESTROCK-FE model describes each process of short- and long-term deformations and failure, the model parameters can be determined using any laboratory experiments with a correlation between the results carried out under any conditions which can be specified by means of boundary conditions while formulating a problem. The paper determined the model parameters relying upon rock-salt sample tests during short-term experiments under compression with a constant deformation velocity.

The requirement of specificity of conditions on the contacts between a sample and press tables during modeling place restrictions on the experimental set up. The specificity of conditions can be achieved in the context of complete sample surface-press table adhesion on the contacts. Under such conditions, non-uniform stress field arises as well as centres of strength weakening within the uniform material. The numerical experiments were carried out for samples in the context of full sample endpress plate contact.

The paper lists the results of numerical experiments carried out for following conditions: long-term creep when load is constant; deformation when unloading takes place after long-term creep deformation; stress relaxation under the specified deformation; and long-term deformation under gradual pressure increase. Results of the numerical experiments correspond to scientific notations.
Scientific sources often use description of creep deformations of rock materials with the help of models, involving Maxwell element; it means that deformation process may be endless at constant load. Long-term modeling examples (up to 10000 hours) show that under certain load levels, creep deformation may tend asymptotically to a constant value. Comparable situation occur in the context of laboratory experiments. If material failure is not in progress then deformations are limited. The unlimited deformation growth results in failure. The assumed model does not describe viscous deformations within the area with acceleration. In the context of the assumed model, both acceleration and the unlimited deformation growth result from the progress of plastic and breaking deformations.

The research has been performed with the use of finite-element model of rock failure (DESTROCK-FE). The activities continue (Olovyannyy \& Chantsev, 2018; Olovyannyy, 2018) materials illustrating DESTROCK-FE possibilities to model processes of rock deformation and failure under different conditions with the use of sample examples during laboratory experiments.

\section{ACKNOWLEDGEMENTS}

The research has been supported by the Institute of Landscape Geoeoclogy of the Russian Academy of Sciences. The materials with the results of rock laboratory tests were represented by scientific research laboratory of physical and mechanical properties and rock failure of Saint-Petersburg Mining University (M.D. Ilinov, Cand. Sc. (Eng.); V.A. Korshunov, Cand. Sc. (Eng.); and D.N. Petrov, Cand. Sc. (Eng.)).

\section{REFERENCES}

Barton, N. (1976). The shear strength of rock and rock joints. International Journal of Rock Mechanics and Mining Sciences \& Geomechanics Abstracts, 13(9), 255-279. https://doi.org/10.1016/0148-9062(76)90003-6

Barton, N. (2013). Shear strength criteria for rock, rock joints, rockfill and rock masses: Problems and some solutions. Journal of Rock Mechanics and Geotechnical Engineering, 5(4), 249-261. https://doi.org/10.1016/i.jrmge.2013.05.008

Glushko, V.T., \& Vinogradov, V.V. (1982). Razrushenie gornykh porod i prognozirovanie gornogo davleniya. Moskva, Rossiya: Nedra.

Il'inov, M.D., Kartashov, Yu.M., Karmanskiy, A.T., \& Kozlov, V.A. (2010). Vliyanie narushennosti gornykh porod na ikh reologicheskie svoystva. Zapiski Gornogo Instituta, (185), 31-36.

Kartashov, Yu.M., Matveev, B.V., Mikheev, G.V., \& Fadeev, A.B. (1979). Prochnost' i deformiruemost' gornykh porod. Moskva, Rossiya: Nedra.

Olovyannyi, A.G. (2016). Lateral earth pressure and tectonic stresses in the mine rock massif. Gornyi Zhurnal, (6), 25-31. https://doi.org/10.17580/gzh.2016.04.05

Olovyannyy, A. (2018). Nonlinear criteria and the influence of the average principal stress on rocks destruction. Mining of Mineral Deposits, 12(4), 37-45. https://doi.org/10.15407/mining12.04.037

Olovyannyy, A.G. (2012). Mekhanika gornykh porod. Modelirovanie razrusheniy. Sankt-Peterburg, Rossiya: IPK Kosta. 
Shen, B., Shi, J., \& Barton, N. (2018). An approximate nonlinear modified Mohr-Coulomb shear strength criterion with critical state for intact rocks. Journal of Rock Mechanics and Geotechnical Engineering, 10(4), 645-652. https://doi.org/10.1016/j.jrmge.2018.04.002

Zhao, B., Liu, D., \& Dong, Q. (2011). Experimental research on creep behaviors of sandstone under uniaxial compressive and tensile stresses. Journal of Rock Mechanics and Geotechnical Engineering, 3(1), 438-444.

https://doi.org/10.3724/SP.J.1235.2011.00438

\section{ЧИСЕЛЬНІ ЕКСПЕРИМЕНТИ ТРИВАЛОГО ДЕФОРМУВАННЯ ЗРАЗКІВ ГІРСЬКИХ ПОРІД}

\section{А. Олов’ яний, В. Чанцев}

Мета. Розвиток методів моделювання процесів тривалого деформування та руйнування зразків гірських порід у різних умовах навантаження за допомогою кінцево-елементного методу моделювання гірських порід, що руйнуються (DESTROCK-FE).

Методика. Модель DESTROCK-FE описує гірську породу як нелінійне пружно-в'язко-пластичне середовище, що руйнується. Деформації повзучості представлені як в'язкопружні, а в'язкопластичні деформації як сума в'язкопружних і руйнуючих деформацій. Деформації руйнування описані моделлю обмеженого числа орієнтованих поверхонь ослаблення, що розраховуються відповідно до критеріїв руйнування на зсув та розрив. Розрахунки виконані методом кінцевих елементів для циліндричних зразків. Чисельні експерименти проведені для наступних умов: тривала повзучість при постійному навантаженні; деформування при знятті навантаження після тривалих деформацій повзучості; релаксація напружень при заданій деформації; тривале деформування при ступінчастому зростанні тиску. У дослідженнях використовувалися зразки кам’яної солі.

Результати. Модель гірської породи як нелінійне пружно-в’язко-пластичне середовище, що руйнується, доповнене моделлю мікродефектного середовища. Встановлено, що загальний характер кривих повзучості гірських порід при постійному навантаженні, при розвантаженні та релаксації напружень, отримані у розрахунках, відповідають існуючим науковим уявленням. Результати свідчать про те, що при побудові моделей гірських порід немає необхідності включати послідовно структурний елемент Максвелла, який визначає нескінченне зростання деформації в часі. Зростання швидкості деформацій на останній стадії деформування зразка зумовлене короткочасним і тривалим накопиченням послаблень та руйнуванням.

Наукова новизна. Доведено, що в’язкі деформації описуються моделлю в'язкопружного середовища, складеної з двох елементів Кельвіна-Фойгта nf елементів короткочасного і тривалого руйнування/

Практична значимість. За результатами моделювання DESTROCK-FE одного зразка, випробуваного при одноосьовому стисканні, можуть бути отримані параметри пружності, пластичності, в'язкості, крихкості, що $\epsilon$ придатними для вирішення геомеханічних та інженерних задач у гірничій справі.

Ключові слова: гірські породи, математичне моделювання, деформації повзучості, релаксація напружень, руйнування, метод кінцевих елементів

\section{ЧИСЛЕННЫЕ ЭКСПЕРИМЕНТЫ ДЛИТЕЛЬНОГО ДЕФОРМИРОВАНИЯ ОБРАЗЦОВ ГОРНЫХ ПОРОД}

\section{А. Оловянный, В. Чанцев}

Цель. Развитие методов моделирования процессов длительного деформирования и разрушения образцов горных пород в различных условиях нагружения с помощью конечно-элементного метода моделирования разрушающихся горных пород (DESTROCK-FE).

Методика. Модель DESTROCK-FE описывает горную породу как нелинейную упруго-вязко-пластическую разрушающуюся среду. Деформации ползучести представлены как вязкоупругие, а вязкопластические деформации как сумма вязкоупругих и разрушающих деформаций. Деформации разрушения описаны моделью ограниченного числа ориентированных поверхностей ослаблений, рассчитываемых в соответствии с критериями разрушения на сдвиг и разрыв. Расчеты выполнены методом конечных элементов для цилиндрических образцов. Численные эксперименты проведены для следующих условий: длительная ползучесть при постоянной нагрузке; деформирование при снятии нагрузки после продолжительных деформаций ползучести; релаксация напряжений при заданной деформации; длительное деформирование при ступенчатом росте давления. В исследованиях использовались образцы каменной соли.

Результаты. Модель горной породы как нелинейная упруго-вязко-пластическая разрушающаяся среда дополнена моделью микродефектной среды. Установлено, что общий характер кривых ползучести горных пород при постоянной нагрузке, при разгрузке и релаксации напряжений, полученные в расчетах, соответствуют существующим научным представлениям. Результаты свидетельствуют о том, что при построении моделей горных пород нет необходимости включать последовательно структурный элемент Максвелла, который определяет бесконечный рост деформации во времени. Рост скорости деформаций на последней стадии деформирования образца обусловлен кратковременным и длительным накоплением ослаблений и разрушением. 
Научная новизна. Доказано, что вязкие деформации описываются моделью вязкоупругой среды, составленной из двух элементов Кельвина-Фойгта и элементов кратковременного и длительного разрушения.

Практическая значимость. По результатам моделирования DESTROCK-FE одного образца, испытанного при одноосном сжатии, могут быть получены параметры упругости, пластичности, вязкости, хрупкости, пригодные для решения геомеханических и инженерных задач в горном деле.

Ключевые слова: горные породы, математическое моделирование, деформации ползучести, релаксация напряжений, разрушение, метод конечных элементов

\section{ARTICLE INFO}

Received: 19 November 2018

Accepted: 12 September 2019

Available online: 4 November 2019

\section{ABOUT AUTHORS}

Anatoliy Olovyannyy, Candidate of Technical Sciences, Principal Researcher of the Saint-Petersburg Branch of the Federal State Budgetary Institution of Science of the Institute of Geoecology named after E.M. Sergeev of the Russian Academy of Sciences, 41 Sredniy Ave., 190004, Saint-Petersburg, Russian Federation. E-mail: agolov2009@hgepro.ru

Valeriy Chantsev, Candidate of Physical and Mathematical Sciences, Associate Professor of the Institute of Industrial Management, Economics and Trade, Peter the Great Saint-Petersburg Polytechnic University, 29 Politekhnicheskaya St, 195251, Saint-Petersburg, Russian Federation. E-mail: chantsev.valery@gmail.com 